\title{
ALBUMIN ADDUCTS AND URINARY METABOLITES RESULTING FROM OCCUPATIONAL EXPOSURE TO 1,5-NAPHTHALENE DIISOCYANATE
}

\author{
OVNAIR SEPAI ${ }^{1}$ and GABRIELE SABBIONI ${ }^{1,2,3}$ \\ ${ }^{1}$ University of Würzburg, Würzburg, Germany \\ Department of Toxicology \\ ${ }^{2}$ Institute of Environmental and Occupational Toxicology, Airolo, Switzerland \\ ${ }^{3}$ University of Munich, Munich, Germany \\ Walther-Straub-Institute of Pharmacology and Toxicology
}

\begin{abstract}
Objectives: 1,5-Naphthalene diisocyanate (NDI) is used in the plastic industry as a curing agent. 1,5-Naphthalene diisocyanate is classified as a sensitizing agent. The objective of this study has been to develop biomonitoring methods for the evaluation of exposure to NDI. Material and Methods: We obtained blood and urine samples from a group of 20 male workers exposed to NDI. The workers answered a questionnaire about their exposure history, job description, the number of years with the company and the time spent working with NDI over the 10 days of the study. Total plasma, albumin, and urine were analyzed for the presence of 1,5-naphthalenediamine (NDA) after acid hydrolysis using gas chromatography-mass spectrometry (GC-MS). Results: 1,5-Naphthalenediamine was found in about $60 \%$ of the samples obtained from the workers. 1,5-Naphthalenediamine was obtained after acid hydrolysis of plasma, albumin, and urine at levels up to $1.5 \mathrm{pmol} \mathrm{NDA} / \mathrm{mg}$ of plasma proteins, $1.15 \mathrm{pmol} \mathrm{NDA} / \mathrm{mg}$ of albumin, and $55.3 \mathrm{pmol} \mathrm{NDA} / \mathrm{ml}$ of urine, respectively. Conclusions: 1,5 -Naphthalenediamine found in urine correlates best with the plasma levels $(r=0.91, p<0.01)$. The albumin-adduct levels did not correlate with the NDI-specific immunoglobulin $\mathrm{E}(\mathrm{IgE})$ or total $\mathrm{IgE}$ present in the workers. The adduct and metabolite levels correlate with the air levels of NDI. Int J Occup Med Environ Health 2017;30(4):579-591
\end{abstract}

Key words:

Diisocyanates, Biomonitoring, Urinary metabolites, Albumin adducts, Arylamine, Occupational hygiene

\section{INTRODUCTION}

Isocyanates are used for manufacturing polyurethane foam, elastomers, paints, adhesives, coatings, insecticides and consolidation of loose rock zones in coal mining or tunneling, and many other products [1,2]. Isocyanates are considered to be one of the main causes of occupational asthma [3-5]. Isocyanate-induced asthma results usually from repeated exposure during which sensitization occurs. After sensitization, even a low level of isocyanate inhalation exposure may induce asthmatic response (reviewed in [6]). Although the respiratory tract has been the focus of most studies on occupational asthma, evidence is

Funding: the Körber-Stiftung. Program manager: Prof. Dietrich Henschler, M.D. (deceased in 2014).

Received: November 30, 2015. Accepted: April 12, 2016.

Corresponding author: G. Sabbioni, Institute of Environmental and Occupational Toxicology, Casella Postale 108, CH-6780 Airolo, Switzerland (e-mail: gabriele.sabbioni@bluewin.ch). 
accumulating that the skin may also play an important role in pathogenesis as an exposure route for initiating immune sensitization [7,8]. Albumin adducts have been linked to the mechanism of occupational asthma caused by isocyanates $[9,10]$. Isocyanate-protein adducts trigger both immune responses and are probably the antigenic basis for isocyanate asthma $[9,11,12]$.

Most toxicological and exposure data concerning aromatic isocyanates has been collected for 4,4'-methylenediphenyl diisocyanate (MDI) and toluene diisocyanate (TDI). A few publications are available for 1,5-naphthalene diisocyanate (NDI) (reviewed in $[13,14]$ ). There is a scarcity of toxicological data for NDI for both animals and man. As with TDI and MDI, a genotoxic and, in the animal experiment, carcinogenic arylamine compound may be formed by hydrolysis of NDI to 1,5-naphthalenediamine (NDA). Therefore, the International Agency for Research on Cancer (IARC) has classified NDI as a class 3 compound [15]. Groups of workers occupationally exposed to NDI either as a vapor or as dust particles have complained of irritation of the eyes, cough, and irritation of the upper respiratory tract $[16,17]$. Lung function tests on these workers showed a reduction in forced vital capacity. Baur et al. [18] described 5 cases with workplace-related asthma and one case with extrinsic allergic alveolitis associated with pulmonary hemorrhage after NDI exposure.

At the workplace, air measurements of isocyanates are performed to protect the workers from too high exposures. However, skin uptake is not considered with such measurements. Urinary metabolites of xenobiotics are usually detectable up to $48 \mathrm{~h}$ after exposure. Risk assessment requires the use of appropriate exposure estimates. In our previous studies with other isocyanates, such as of MDI, the air levels of MDI were below the detection limit except for few cases [19-21]. Blood protein adducts reflect the exposure history over a longer period of time than urinary metabolites [22] or than metabolites present in serum. Hemoglobin adducts have a lifetime of 120 days and albumin adducts - a half-life of 20-25 days [23,24]. Reaction products with hemoglobin accumulate up to 60 times $[23,25]$ a single dose and albumin adducts up to 29 times [26] a single dose. Blood protein adducts are excellent markers of exposure [27]. Furthermore, albumin is one of the potential targets involved in the etiology of sensitization reactions of isocyanates $[9,28]$.

The hydrolysis products of the isocyanates, namely the amines, have been detected in the biological fluids of exposed humans and animals. The urinary levels of the corresponding aromatic amines obtained after acid hydrolysis were determined for MDI [19,20,29,30], TDI [31] and NDI [32-34]. Hemoglobin adducts of MDI were found in humans [19] and in rats [35]. 1,5-Naphthalenediamine (NDA) was found in plasma after base hydrolysis [32]. 4,4'-Methylenedianiline (MDA) was found in plasma after acid hydrolysis [29] and after base hydrolysis [32]. 4,4'-Methylenedianiline could be released from albumin-adducts [20] in workers exposed to MDI.

In this study, we have investigated the presence of NDI derivatives in the urine and blood of workers exposed to NDI. These workers had contact with NDI in the form of a powder and were exposed to the vapor from pyrolysis of sheets or pellets of polyurethane during the manufacture of parts for the automobile industry. The levels of NDA (Figure 1) released after acid hydrolysis from albumin, plasma and urine were determined using gas chromatography-mass spectrometry (GC-MS) and compared to the air levels monitored in the work halls (using static monitors), with personal monitors and with immunological parameters.

\section{MATERIAL AND METHODS \\ Workers}

Twenty male workers and 2 members of clerical staff not associated with the factory floor (factory controls) gave their written consent before participating in this study. 


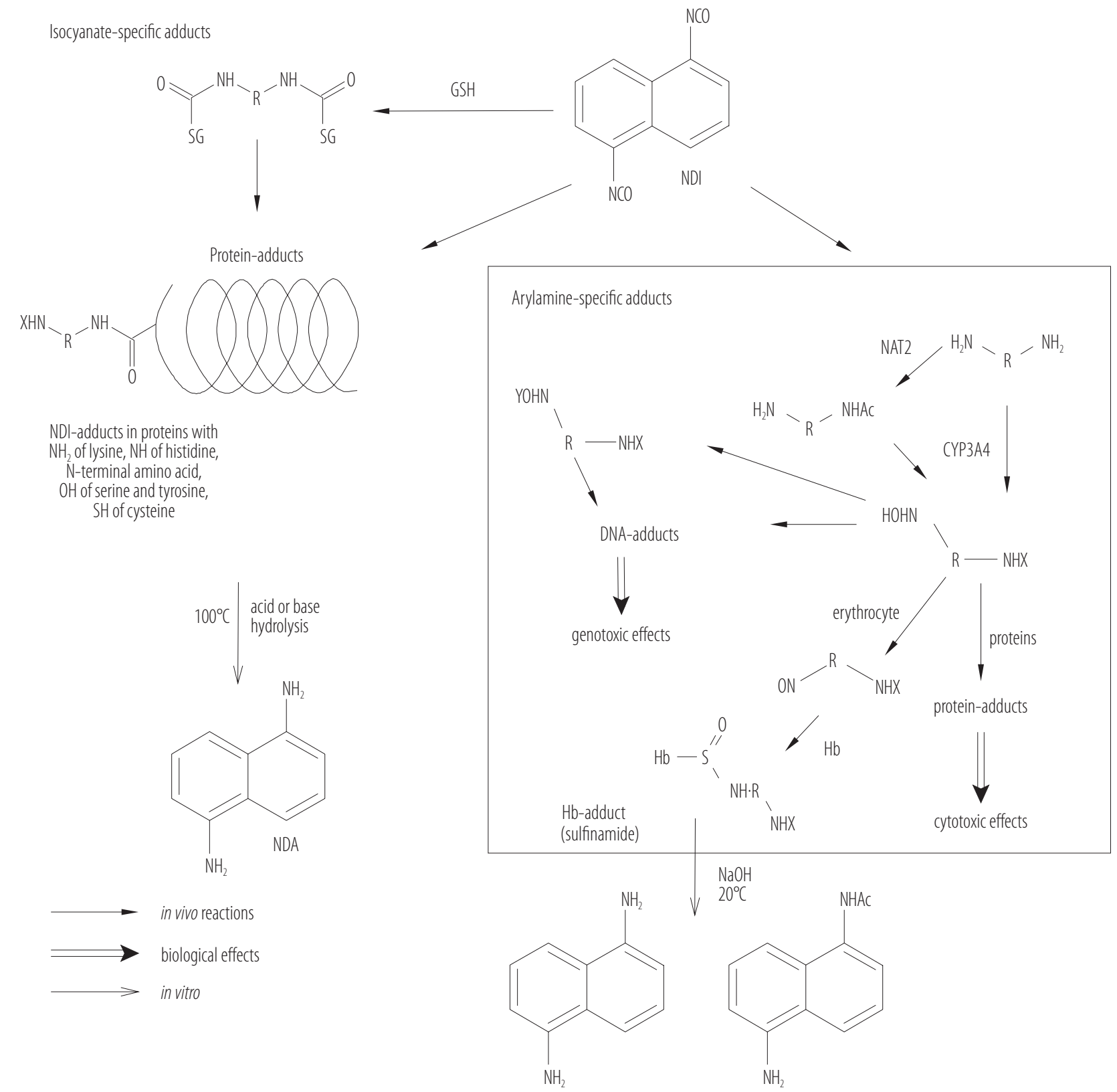

$\mathrm{R}$ - naphthyl; X - hydrogen or acetyl (Ac); GSH - gluthathione; Hb - hemoglobin; $\mathrm{Y}_{1}$ - $\mathrm{SO}_{3}$; $\mathrm{Y}_{2}$ - acetyl (Ac).

Fig. 1. Potential reaction products of 1,5-naphthalene diisocyanate (NDI) with biomolecules

The results were summarized and presented as a talk to the members of the factory. Each volunteer answered a simple questionnaire and gave urine and blood samples at the end of a working week. The answers have been summarized in the Table 1 and in Sepai et al. [20].

\section{Chemicals}

For the analytical work the following solvents, chemicals and materials were purchased from: Merck (Darmstadt, Germany); water (chromatography grade, No. 15333), diethyl ether (pro analysis (p.a.)), ethyl acetate (residue analysis 
Table 1. Characteristics of 20 male workers occupationally exposed to 1,5-naphthalene diisocyanate (NDI) and 2 female controls

\begin{tabular}{|c|c|c|c|c|c|c|c|c|}
\hline \multicolumn{5}{|c|}{ Workers } & \multicolumn{2}{|c|}{ Workplace } & \multicolumn{2}{|c|}{ Biomarker } \\
\hline No. & job & $\begin{array}{c}\text { age } \\
\text { [years] }\end{array}$ & $\begin{array}{l}\text { seniority }^{a} \\
\text { [years] }\end{array}$ & $\begin{array}{c}\text { time handling NDI } \\
{[\%]^{\mathrm{b}}}\end{array}$ & $\begin{array}{c}\text { air NDI levels } \\
{\left[\mu \mathrm{g} / \mathrm{m}^{3}\right]}\end{array}$ & $\begin{array}{l}\text { work hall } \\
\text { No. }\end{array}$ & $\begin{array}{c}\text { Rast-NDI } \\
\text { [RU] }\end{array}$ & $\begin{array}{l}\text { IgE total } \\
{[\mathrm{PU}]}\end{array}$ \\
\hline \multicolumn{9}{|c|}{ Study group } \\
\hline 1 & granulation machine & 36 & 8 & 0 & $-^{c}$ & 4 & 0.77 & 14.4 \\
\hline 2 & casting machine & 47 & 20 & 0 & $82^{\mathrm{d}}$ & 2 & 1.19 & 109.4 \\
\hline 3 & extruder & 31 & 5 & 0 & $-^{\mathrm{c}}$ & 2 & 1.15 & 40.7 \\
\hline 4 & pressure chamber & 39 & 15 & 0 & $-^{c}$ & 2 & 1.27 & 12.0 \\
\hline 5 & conveyor belt & 30 & 4 & 0 & $-^{c}$ & 4 & 1.19 & 162.6 \\
\hline 6 & casting machine & 34 & 9 & 0 & $-^{c}$ & 2 & 0.92 & 7.3 \\
\hline 7 & tension cutting machine & 51 & 26 & 0 & $<1$ & 3 & 1.27 & 266.3 \\
\hline 8 & casting machine & 36 & 15 & 40 & $82^{\mathrm{d}}$ & 4,2 & 1.06 & 23.7 \\
\hline 9 & tension cutting machine & 55 & 30 & 0 & $<1$ & 3 & 0.60 & 23.9 \\
\hline 10 & $\begin{array}{l}\text { supervisor of granulation } \\
\text { machine }\end{array}$ & 51 & 30 & 0 & $-^{\mathrm{c}}$ & 4 & 1.01 & 10.0 \\
\hline 11 & casting machine & 30 & 10 & 78 & $82^{\mathrm{d}}$ & 4,2 & 0.92 & 120.8 \\
\hline 12 & casting machine & 55 & 26 & 100 & 9 & 2 & 1.06 & 137.7 \\
\hline 13 & $\begin{array}{l}\text { granulator, extruder and } \\
\text { caster }\end{array}$ & 35 & 15 & 0 & $-c, d$ & 4 & 0.83 & 32.7 \\
\hline 14 & spinning plate & 44 & 22 & 8.5 & $9^{\mathrm{d}}$ & 2 & 1.28 & 4.6 \\
\hline 15 & fitter, lathe operator & 55 & 31 & 0 & $<1$ & 3 & 1.53 & 17.2 \\
\hline 16 & extruder & 29 & 5 & 0 & 5 & 2 & 0.90 & 188.3 \\
\hline 17 & conveyor belt & 26 & 4 & 0 & $1^{\mathrm{d}}$ & 3 & & \\
\hline 18 & stoker & 56 & 25 & 0 & $82^{\mathrm{d}}$ & 2 & 1.25 & 27.5 \\
\hline 19 & maintenance of molds & 57 & 32 & 0 & $-^{c}$ & 1 & 0.99 & 153.0 \\
\hline 20 & supervisor & 52 & 26 & 0 & 2.6 & 3 & 1.37 & 16.4 \\
\hline \multicolumn{9}{|c|}{ Control group } \\
\hline-1 & receptionist & 55 & 5 & 0 & n.m. & - & 1.09 & 275.9 \\
\hline-2 & clerical staff & 54 & 12 & 0 & n.m. & - & 0.98 & 36.6 \\
\hline
\end{tabular}

Rast-NDI - radio-allergo-sorbent-test for NDI specific IgE; RU - relative unit; IgE - immunoglobulin E; PU - paper radioimmunosorbent test U/ml; n.m. - not monitored.

${ }^{a}$ Working for the company.

${ }^{\mathrm{b}}$ In the previous 10 working days.

${ }^{\mathrm{c}}$ No positive value detected.

${ }^{\mathrm{d}}$ Air measurement from a personal monitor, all other values are from the work hall or work station monitors.

grade); Reidel-de Haen (Selze, Germany), dichloromethane (Pestanal); Sigma (Deisenhofen, Germany), HiTrap ${ }^{\text {TM }}$ Blue cartridges (1 ml capacity), total protein assay biuret reagent and protein standard solution, human albumin; Pierce (The
Netherlands), Coomassie ${ }^{\circledR}$ Plus Protein Assay; and Fluka (Buchs, Switzerland); heptafluorobutyric anhydride (HFBA), hydrochloric acid (HCl) 37\%, (for trace analysis, No. 84415; Fluka). All other chemicals were obtained of p.a. grade. 


\section{Sample collection}

Each participant completed a simple questionnaire enquiring into their work history, exposure to NDI in the past 10 working days, and job description. Blood and urine samples were collected at the end of a working week and immediately transported to the laboratory on ice. Air monitors were used for detecting ambient air levels of NDI in the work rooms and personal air levels [36]. In some cases, monitors were placed near a particular piece of equipment where a potentially high risk of exposure was present.

\section{Isolation of albumin from plasma and acid hydrolysis}

Using a HiTrap ${ }^{\mathrm{TM}}$ Blue affinity column (1 ml volume) an albumin fraction was isolated from plasma as follows: Plasma $(0.5 \mathrm{ml})$ was diluted $1: 1$ with buffer $\mathrm{A}(50 \mathrm{mM}$ of potassium dihydrogen phosphate $\left(\mathrm{KH}_{2} \mathrm{PO}_{4}\right), 10 \mathrm{mM}$ of sodium azide $\left.\left(\mathrm{NaN}_{3}\right), \mathrm{pH}=7.2\right)$ and loaded onto the column. Fraction A was eluted using buffer A $(2 \mathrm{ml})$, the column was then washed with buffer $\mathrm{B}(2 \mathrm{ml})\left(50 \mathrm{mM}\right.$ of $\mathrm{KH}_{2} \mathrm{PO}_{4}, 10 \mathrm{mM}$ of $\mathrm{NaN}_{3}, 100 \mathrm{mM}$ of potassium chloride $(\mathrm{KCl}), \mathrm{pH}=7.2$ ) (fraction B). Albumin was then eluted with buffer $\mathrm{C}$ (2 ml) $\left(50 \mathrm{mM}\right.$ of $\mathrm{KH}_{2} \mathrm{PO}_{4}, 10 \mathrm{mM}$ of $\mathrm{NaN}_{3}, 2 \mathrm{M}$ of $\mathrm{KCl}$, $\mathrm{pH}=7.2$ ) (fraction $\mathrm{C}$ ). The column was washed with buffer C (2 ml) (fraction D). The albumin concentration was determined using Coomassie Blue Plus protein analysis reagent (Pierce) with human albumin as the reference protein. The protein content of each plasma sample was also determined using a total protein assay (Sigma) and the appropriate protein standard. From fractions $\mathrm{C}$ (albumin) the protein was precipitated with 4 volumes $(8 \mathrm{ml})$ of ethanol. After $30 \mathrm{~min}$ on ice, the solid albumin was collected by centrifugation and washed with ethanol, ethanol:diethyl ether 1:3, and with diethyl ether. The albumin was dissolved in water $(2 \mathrm{ml})$ and concentrated $\mathrm{HCl}(1 \mathrm{ml}, 37 \%)$ was added. The solution was hydrolyzed for $60 \mathrm{~min}$ at $100^{\circ} \mathrm{C}$ in order to hydrolyze the NDI-albumin adducts. After adjusting the $\mathrm{pH}$ to between 9 and 10 with sodium hydroxide $(\mathrm{NaOH})(32 \%)$, the solution was spiked with deuterated 4,4'-methylenedianiline (d $\mathrm{d}_{4}$-MDA) (5.02 pmol). The released amines were extracted and derivatized as described in "Extraction and derivatization."

\section{Acid hydrolysis of urine}

4-Methylaniline (4MA) $(24 \mu \mathrm{g})$ and $\mathrm{HCl}(0.5 \mathrm{ml}, 37 \%)$ were added to urine $(1 \mathrm{ml})$ in $10 \mathrm{ml}$ screw top vials fitted with Teflon liners. The hydrolysis was carried out for $30 \mathrm{~min}$ at $100^{\circ} \mathrm{C}$. Then the solution was cooled and made basic with $\mathrm{NaOH}(800 \mu l, 32 \%)$. The internal standard $\mathrm{d}_{4}$-MDA (5.02 pmol) was added and the solution was extracted and derivatized as described in "Extraction and derivatization."

\section{Acid hydrolysis of plasma}

The protein content of each plasma sample was determined using the Sigma total protein assay and the appropriate protein standard. $24 \mu \mathrm{g} 4 \mathrm{MA}, 0.5 \mathrm{ml}$ of water, and $0.5 \mathrm{ml}$ of $37 \%$ hydrochloric acid were added to $0.5 \mathrm{ml}$ of plasma. The samples were hydrolyzed for $60 \mathrm{~min}$ at $100^{\circ} \mathrm{C}$. Then the solution was cooled and made basic with $\mathrm{NaOH}(800 \mu \mathrm{l}, 32 \%)$. The internal standard $\mathrm{d}_{4}$-MDA (5.02 pmol) was added and the solution was extracted and derivatized as described in "Extraction and derivatization."

\section{Extraction and derivatization}

The amines were extracted from basic solution into dichloromethane $(5 \mathrm{ml})$, the solutions were vortexed for $2 \mathrm{~min}$ and then centrifuged for $10 \mathrm{~min}$ at $2000 \mathrm{~g}$. The organic layer was carefully removed and passed through a Pasteur pipette filled with anhydrous sodium sulfate. The drying agent was rinsed with $1 \mathrm{ml}$ of dichloromethane. The pooled organic extracts were treated with $5 \mu$ l of HFBA to derivatize the amines present in the extracts, after $10 \mathrm{~min}$ at room temperature the reaction was stopped by the addition of 4MA $(24 \mu \mathrm{g})$ in methanol $(50 \mu \mathrm{l})$. The solutions were 
then taken down to dryness using a vacuum-centrifuge (Speed-Vac, Univap, Martinsried, Germany). The residue was transferred into microinserts with $2 \times 50 \mu \mathrm{l}$ of ethyl acetate and dried again. The final extracts were taken up in $15 \mu \mathrm{l}$ of ethyl acetate and analyzed by GC-MS.

\section{GC-MS analysis}

Aliquots of $1 \mu \mathrm{l}$ from acid extracts were injected splitless on to a XTI-5 column $(15 \mathrm{~m} \times 0.25 \mathrm{~mm}, 0.25 \mu \mathrm{m}$ film thickness) (Restek, Germany) with a $1.5 \mathrm{~m} \times 0.25 \mathrm{~mm}$ retention gap (methyl-silyl deactivated, Analyt, Germany). The initial oven temperature of $50^{\circ} \mathrm{C}$ was held for $1 \mathrm{~min}$ and then ramped at $40^{\circ} \mathrm{C} / \mathrm{min}$ to $290^{\circ} \mathrm{C}$ where it was held for $1 \mathrm{~min}$. The purge valve was activated after $1 \mathrm{~min}$, the injector and interface temperatures were set to $320^{\circ} \mathrm{C}$ and $300^{\circ} \mathrm{C}$, respectively. The GC column was directly interfaced with a Hewlett Packard 5989A quadrupole mass analyzer. All analyses were carried out in the negative chemical ionization (NCI) mode using methane as the reagent gas and an electron energy of $240 \mathrm{eV}$. The source pressure and temperature were held at 1.1 Torr and $250^{\circ} \mathrm{C}$. The $[\mathrm{M}-\mathrm{HF}]^{-}$ (molecular mass minus hydrogen fluoride) fragments were monitored with a dwell time of $100 \mathrm{~ms}$ : m/z 574 for $\mathrm{d}_{4}$-MDA; and m/z 530 for NDA. 1,5-Naphthalenediamine and $\mathrm{d}_{4}$-MDA eluted after $4.3 \mathrm{~min}$ and $5.4 \mathrm{~min}$, respectively.

\section{Quantitation of NDA}

Calibration lines were run with each batch of samples. Control urine and plasma samples were spiked with the internal standard ( $\mathrm{d}_{4}$-MDA, $\left.5.02 \mathrm{pmol}\right)$ and NDA at 5 concentrations from 0.1 to $2 \mathrm{ng} \mathrm{NDA} / \mathrm{ml}$ of urine, 0.1 to $1 \mathrm{ng} \mathrm{NDA} / \mathrm{ml}$ of plasma and 0.1 to $1 \mathrm{ng} \mathrm{NDA} / 100 \mathrm{mg}$ of albumin. The samples were then hydrolyzed and worked up as described above. The ratios of the area integrals of NDA to $d_{4}$-MDA were then plotted against the amount of NDA. The calibration lines were linear in all cases. All the samples were quantified against these calibration lines. The variance of the recoveries $(\mathrm{N}=3)$ and the following correlation coefficients were obtained: for plasma ( $0.1 \mathrm{ng} / \mathrm{ml}$ (relative standard deviation: $5.6 \%)$ to $1 \mathrm{ng} / \mathrm{ml}(7 \%), \mathrm{r}=0.955)$, for urine $(0.1 \mathrm{ng} / \mathrm{ml}(10 \%)$ to $2 \mathrm{ng} / \mathrm{ml}(6 \%), \mathrm{r}=0.996)$. The precision of replicate $(\mathrm{N}=5)$ analysis of plasma and urine from worker number 14 was $0.492( \pm 8.13 \%) \mathrm{pmol} / \mathrm{mg}$ of total plasma proteins, and $46( \pm 2 \%) \mathrm{pmol} / \mathrm{ml}$ of urine. The limit of quantitation (LOQ) (background level +10 standard deviations [37]) for the albumin, plasma and urine analyses was $0.08 \mathrm{pmol} / \mathrm{mg}, 0.08 \mathrm{pmol} / \mathrm{mg}$ and $0.4 \mathrm{pmol} / \mathrm{ml}$, respectively.

\section{Determination of immunological parameters}

The immunological methods were published previously in detail [21]. The tests were applied routinely in the laboratory of Dr. J. Lewalter (Bayer AG, Leverkusen).

Total immunoglobulin E ( $\mathrm{IgE}$ ) levels in sera were determined using the Paper Radioimmunosorbent Test (PRIST) kit from Pharmacia and values were expressed in PRIST $\mathrm{U} / \mathrm{ml}$ (PU). The isocyanate specific $\operatorname{IgE}$ were determined with the Radio-Allergo-Sorbent-Test (RAST). The relative unit (RU) (antigen disc/human serum albumin (HSA) disc) is yielded from the radioactivity counts of the discs.

\section{Statistical analyses}

The statistical analyses were performed with the program IBM-SPSS 19.0. The data was plotted with the program SigmaPlot 10.0.

\section{RESULTS}

\section{Air levels of NDI}

The air levels of NDI [36] were monitored over a period of 10 working days by either workroom or workstation monitors. The levels ranged from 2 to $9 \mathrm{mg} / \mathrm{m}^{3}$ in $6(30 \%)$ of the subjects studied (i.e., workers 2, 8, 11, 12, 14, and 18) (Table 1). In contrast, levels as high as $82 \mathrm{mg} \mathrm{NDI} / \mathrm{m}^{3}$ were detected from 4 (57\%) out of the 7 personal moni- 
tors (i.e., workers 2, 8, 11, 18). Workers 2, 8, 11, and 18 worked in the hall number 2 during the 10 days of the study and all, except for the number 18, were associated with the casting machine. During the casting process, NDI was mixed with other components and poured into casts, where the polyurethane was molded at high temperature. Temperatures up to $34^{\circ} \mathrm{C}$ were recorded near the casting machine in the hall 2 whereas the ambient factory temperature ranged from 22 to $24^{\circ} \mathrm{C}$.

\section{Urinary metabolite}

All urine samples were acid-hydrolyzed before extraction in order to cleave NDA from possible conjugates.
1,5-Naphthalenediamine was found for 12 workers and 1 control. The concentration ranged from LOQ to 55 pmol NDA per $\mathrm{ml}$ of urine. The highest urinary levels of NDA (above $10 \mathrm{pmol} / \mathrm{ml}$ ) were detected from workers 2, 8, 12 and 14 (Figures 2 and 3). Urinary metabolites constituted the reflection of recent exposure. Workers 8 and 12 handled NDI (Table 1) whereas workers 2 and 14 reported no direct contact with NDI but were associated with the casting machine in the hall 2. The air levels associated with workers 12 and 14 were low $\left(9 \mu \mathrm{g} / \mathrm{m}^{3}\right)$ but their urinary levels were very high. In contrast, worker 11 was associated with the casting machine, he had direct contact with NDI and his personal

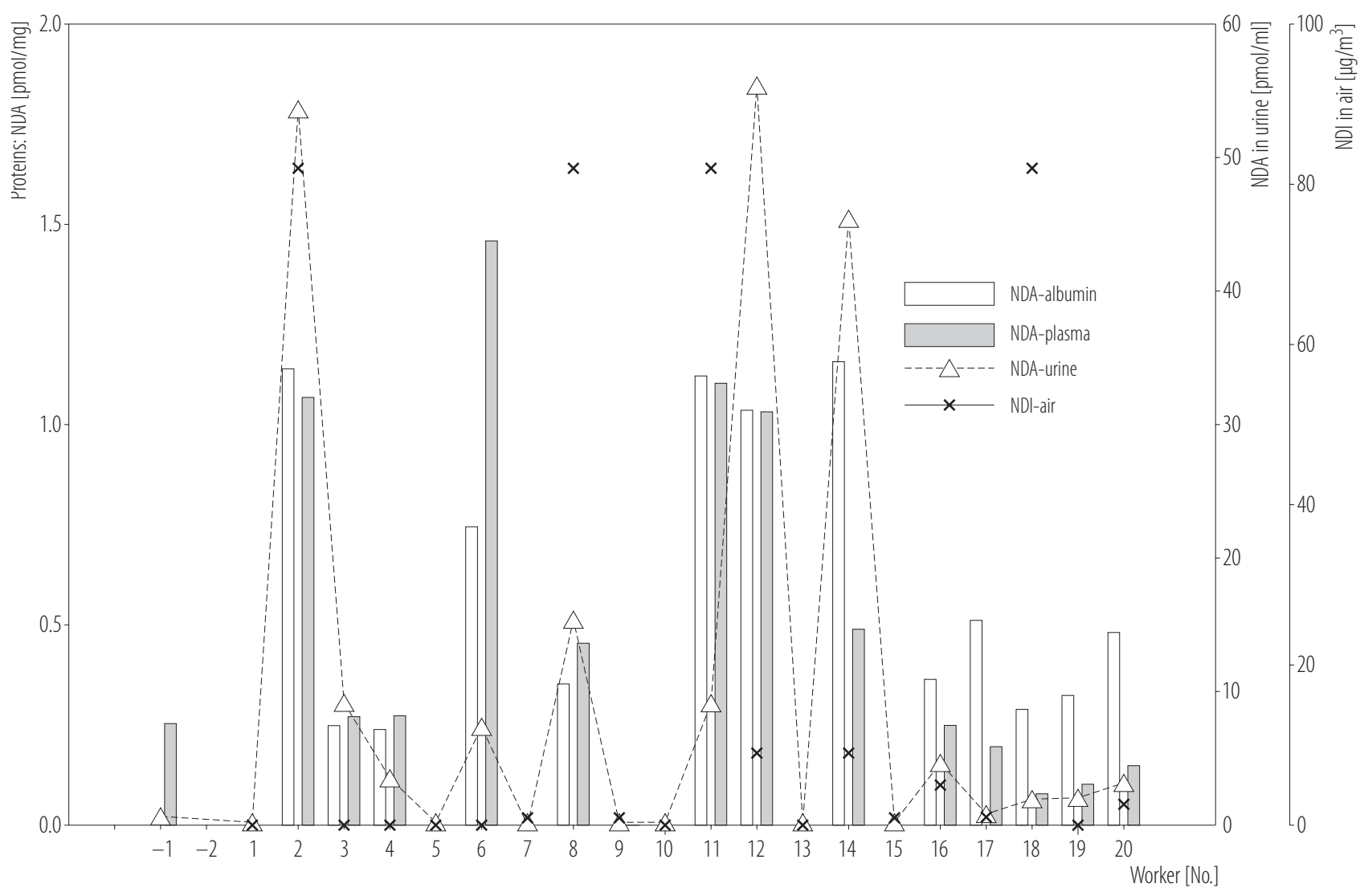

NDI - 1,5-naphthalene diisocyanate.

Worker No. -1 and No. -2 are factory controls.

Fig. 2. 1,5-Naphthalenediamine (NDA) released from albumin, total plasma and urine by acid hydrolysis and analyzed by gas chromatography-mass spectrometry (GC-MS) 


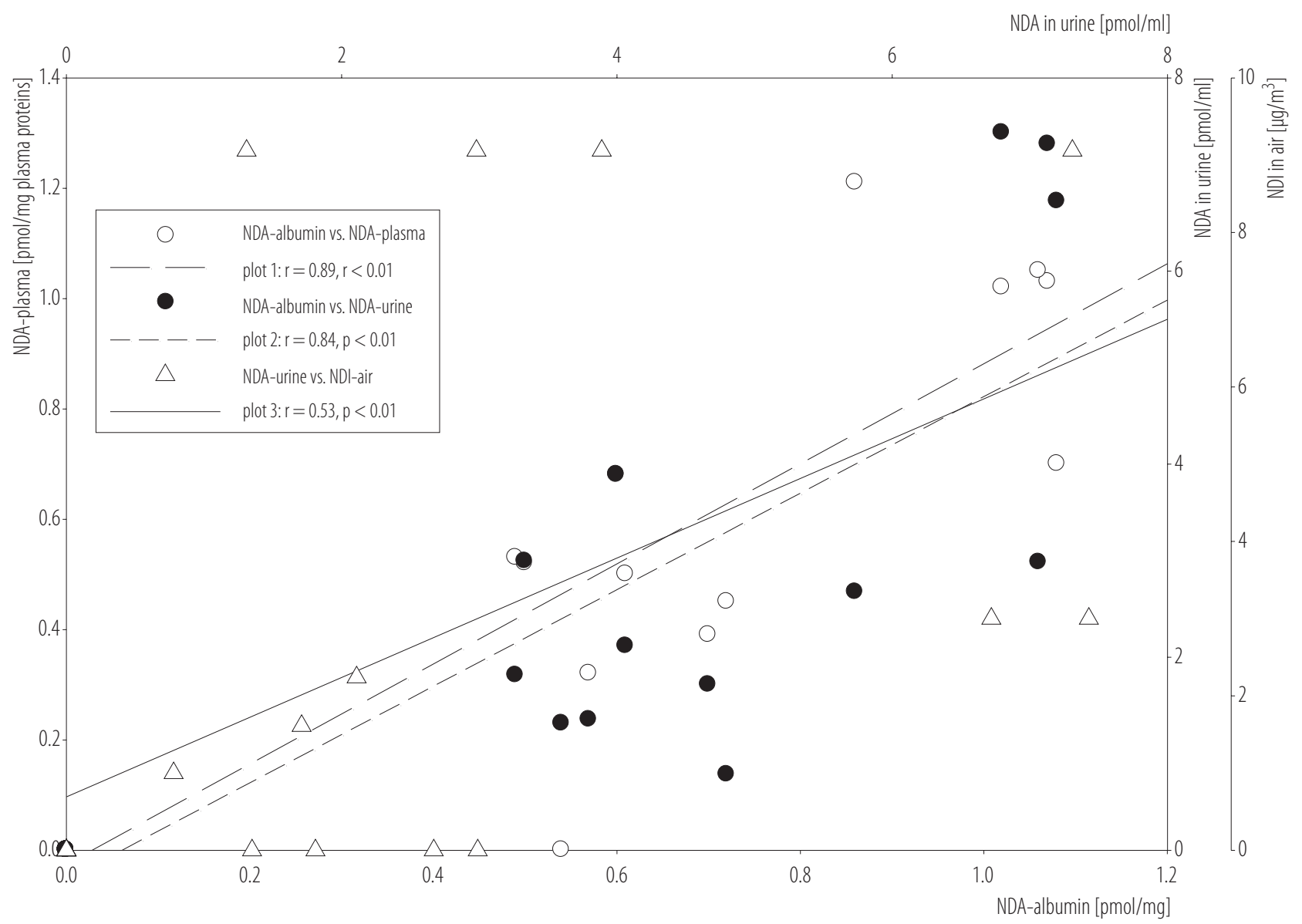

The data was square-rooted in order to obtain normal distribution.

Abbreviations as in Figure 2.

Fig. 3. Correlations of the albumin adducts, plasma protein adducts, urinary metabolites and the air levels of 1,5-naphthalene diisocyanate (NDI) measured for the 20 workers

monitor detected an air level of $82 \mu \mathrm{g} / \mathrm{m}^{3}$. However, his urinary level of NDA was below $10 \mathrm{pmol} / \mathrm{ml}$. These results indicate that air levels do not reflect urinary metabolite levels and, therefore, may not provide a suitable gauge of exposure.

\section{Blood plasma analysis}

Plasma protein conjugates have been implicated in processes, which stimulate immunological responses to isocyanates [9,38]. In this study, we have determined the concentration of NDA in plasma and the amount covalently bound to albumin. The protein content of each plasma sample was determined using a total protein assay. Acid hydrolysis of plasma samples released from LOQ to 1.45 pmol of NDA per mg of protein and from LOQ to $111 \mathrm{pmol}$ per $\mathrm{ml}$ of plasma. Positive samples were found for 13 samples from workers. Levels above $0.2 \mathrm{pmol} / \mathrm{mg}$ were detected from 10 workers, 5 out of whom were associated with the casting machine (Figures 2 and 3, Table 1). Those who exclusively worked in the hall 4 (i.e., 1, 5, 10, 13) showed the lowest NDA levels. This is not surprising, as NDI was not used in the hall 4. 


\section{Albumin adducts}

Albumin was isolated using a Cibacron Blue affinity chromatography column. Albumin was precipitated and washed with a series of organic solvents. The isolated albumin was analyzed for the presence of NDA. AlbuminNDA adducts were detected for 13 workers in the range of LOQ to $1.15 \mathrm{pmol} / \mathrm{mg}$ (Figures 2 and 3). Control plasma samples spiked with NDA were worked up following the same procedure, acid hydrolysis of the isolated plasma liberated no NDA, and thus, any non-covalently bound metabolites were removed during the work up procedure. This indicates that the NDA detected is covalently bound to albumin. The structure of these adducts is under investigation. No values are present in the literature for NDI bound to albumin.

\section{Immunological methods}

The range of the $\mathrm{IgE}$ levels in the exposed workers was 4.6-266.3 PU (14.4, 27.5, 138, 188 PU) (25th, 50th, 75th, 95th percentile, respectively). The range of the isocyanate specific IgE-NDI was 0.6-1.53 RU $(0.92,1.06,1.27$, 1.37 RU). All the RU were below 2, which was the threshold for positive results.

\section{DISCUSSION}

The plasma levels of NDA were determined in the past. The plasma levels found in this work were 3.5 times lower than the values published by Sennbro et al. [32] (3.2-380 $\mathrm{pmol} / \mathrm{ml}$ plasma). Sennbro et al. refluxed the samples in $0.3 \mathrm{M} \mathrm{NaOH}$ for $24 \mathrm{~h} \mathrm{[32].} \mathrm{We} \mathrm{refluxed}$ our samples for $0.5 \mathrm{~h}$ in $4 \mathrm{M} \mathrm{HCl}$. The urinary levels of this study were approximately 10 times lower than the values published by Sennbro et al.: 3.9-521 pmol/ml [32]. However, Sennbro et al. [32] used longer hydrolysis times (0.3 M NaOH, $100^{\circ} \mathrm{C}, 24 \mathrm{~h}$ ). Such conditions yielded higher values as studied systematically with synthesized adducts [39] or as studied in the analysis of toluene diisocyanate exposed workers [40]. We chose to use shorter hydrolysis time since the same conditions were applied to the analysis of MDI-adducts in the same workers [20]. All hydrolysis conditions used in biomonitoring studies, which yield the parent compounds, usually do not indicate the form of the cleaved adducts. With the advance of the liquid chromatography-mass spectrometry (LC-MS) technology it is advisable to measure the intact adducts, as described in recent studies of our group for MDI exposed workers [41]. However, these new techniques are much more sophisticated and expensive. For a quick and inexpensive biomonitoring method, the hydrolyses of the adducts with base and acid have still its place in occupational hygiene. The biomarkers obtained with acid or base hydrolyses methods indicate the exposure of the workers to isocyanates and/or the corresponding amine. Air monitoring is not sufficient to establish the exposure of workers $[19,42]$. In order to distinguish between aromatic amine and isocyanate exposure, the intact adducts with the amino acids should be analyzed.

Spearmen rank correlation analyses (2-tailed significance) were performed with the data of the 20 workers. The albumin adduct levels correlate with the air levels $(r=0.74$, $\mathrm{p}<0.01)$, plasma levels $(\mathrm{r}=0.87, \mathrm{p}<0.01)$ and the urinary levels $(\mathrm{r}=0.86, \mathrm{p}<0.01)$. In addition the urinary levels correlate with the plasma levels $(\mathrm{r}=0.91, \mathrm{p}<0.01)$ and the air levels $(r=0.67, p<0.01)$. The Pearson correlation analysis (2-tailed significance) was performed with square-rooted data in order to have a normal distribution of the numbers according to the one sample KolmogorovSmirnov test. The albumin adduct levels correlate with the air levels ( $r=0.57, p<0.01)$, plasma levels $(r=0.89$, $p<0.01)$ and the urinary levels $(r=0.84, p<0.01)$. In addition the urinary levels correlate with the plasma levels $(\mathrm{r}=0.80, \mathrm{p}<0.01)$ and the air levels $(\mathrm{r}=0.53$, $\mathrm{p}<0.01)$. Therefore, urinary metabolite levels are good exposure markers. The determination of albumin adducts would not be necessary. The determination of urinary metabolites is less invasive and less expensive. For this 
population, the NDI adduct or the urinary levels of NDA do not correlate with the total IgE levels or the NDI-specific antibody levels. The presence of NDA in one control is not unusual $[19,20]$. Protein adducts are long-term exposure markers. Therefore, the workers have to be able to recall their exposure history for the last 4 months.

The levels of the biomarkers found in the same workers exposed to MDI [20] were up to 20-fold lower than the corresponding NDI-biomarkers. However, the air levels were up to 5 times lower and only 3 air samples were positive for MDI, but 12 air samples were positive for NDI. Therefore, NDI exposure was higher in this set of workers.

The range of the MDI specific IgE was in the same order of magnitude 0.54-1.44 RU (0.92, 0.99, 1.12, 1.36, that is 25 th, 50th, 75th, 95th percentile, respectively) as for the NDI specific IgE. The specific NDI-IgEs or the total IgEs do not correlate (Spearman rank correlation) with the NDI-biomarkers. In contrast, the MDI-adduct levels [20] correlate (Spearman rank correlation, $r=-0.46$, $\mathrm{p}=0.047$ ) inversely with the total IgE-levels (data not shown in the original publication). However, the MDIadduct levels did not correlate with MDI-specific IgE (MDI-RAST test). All the NDI biomarkers did not correlate with the MDI-biomarker [20] levels measured previously in the same workers.

The mechanisms leading to the onset of occupationally induced asthma or other disorders attributed to isocyanate exposure are still unclear: immunologic and hypersensitivity type mechanisms have been proposed [4]. As albumin conjugates of MDI have been shown to produce a weak immediate type respiratory hypersensitivity in previously sensitized guinea pigs [38], we may predict similar responses to albumin conjugates of NDI. Raised levels of $\mathrm{IgE}$ antibodies to human serum albumin-MDI conjugates have been observed in both guinea pigs and exposed workers [43]. Whether the NDI-adducts detected in the workers at issue play a part in the irritation or sensitization responses to NDI is still not certain.

\section{CONCLUSIONS}

Most of these workers have a long employment history (Table 1) and are therefore not likely to be either sensitive or sensitized (i.e., asymptomatic individuals). The use of metabolites or protein adducts as biomarkers of exposure, as opposed to air level measurements, are proposed as a more reliable form of control of exposure in the workplace. As the adduct and metabolite levels from these workers are at significantly high concentrations it may be concluded that the work environment is not suitably ventilated.

\section{ACKNOWLEDGMENTS}

We are grateful to Dr. Jürgen Lewalter of Bayer, Leverkusen, for the air and the immunological determination. We acknowledge the technical assistance of Elisabeth Stein.

\section{REFERENCES}

1. Adam N, Avar G, Blankenheim H, Friederichs W, Giersig M, Weigand E, et al. Polyurethanes. Ullmann's Encyclopedia of Industrial Chemistry. Weinheim: Wiley-VCH Verlag GmbH \& Co. KGaA; 2000, https://doi.org/10.1002/14356007.a21_665.pub2.

2. Brochhagen F. Isocyanates. In: Hutzinger O, editor. The handbook of environmental chemistry. Berlin: Springer; 1991. p. 1-95, https://doi.org/10.1007/978-3-540-46757-1_1.

3. Karol MH. Respiratory effects of inhaled isocyanates. Crit Rev Toxicol. 1986;16(4):349-79, https://doi.org/10. 3109/10408448609037467.

4. Baur X, Marek W, Ammon J, Czuppon AB, Marczynski B, Raulf-Heimsoth M, et al. Respiratory and other hazards of isocyanates. Int Arch Occup Environ Health. 1994;66(3): 141-52, https://doi.org/10.1007/BF00380772.

5. Bernstein JA. Overview of diisocyanate occupational asthma. Toxicology. 1996;111(1-3):181-9, https://doi.org/10.1016/ 0300-483X(96)03375-6.

6. Lummus ZL, Wisnewski AV, Bernstein DI. Pathogenesis and disease mechanisms of occupational asthma. Immunol Allergy Clin North Am. 2011;31(4):699-716, https://doi. org/10.1016/j.iac.2011.07.008. 
7. Rattray NJ, Botham PA, Hext PM, Woodcock DR, Fielding I, Dearman RJ, et al. Induction of respiratory hypersensitivity to diphenylmethane-4,4'-diisocyanate (MDI) in guinea pigs. Influence of route of exposure. Toxicology. 1994;88(1-3): 15-30, https://doi.org/10.1016/0300-483X(94)90108-2.

8. Bello D, Herrick CA, Smith TJ, Woskie SR, Streicher RP, Cullen MR, et al. Skin exposure to isocyanates: Reasons for concern. Environ Health Perspect. 2007;115(3):328-35, https://doi.org/10.1289/ehp.9557.

9. Raulf-Heimsoth M, Baur X. Pathomechanisms and pathophysiology of isocyanate-induced diseases - Summary of present knowledge. Am J Ind Med. 1998;34(2):137-43, https://doi.org/10.1002/(SICI)1097-0274(199808)34:2<137:: AID-AJIM6>3.0.CO;2-U.

10. Wisnewski AV. Developments in laboratory diagnostics for isocyanate asthma. Curr Opin Allergy Clin Immunol. 2007;7(2):138-45, https://doi.org/10.1097/ACI.0b013e3280 $895 \mathrm{~d} 22$.

11. Ye YM, Kim CW, Kim HR, Kim HM, Suh CH, Nahm DH, et al. Biophysical determinants of toluene diisocyanate antigenicity associated with exposure and asthma. J Allergy Clin Immunol. 2006;118(4):885-91, https://doi.org/10.1016/ j.jaci.2006.06.026.

12. Bernstein JA, Munson J, Lummus ZL, Balakrishnan K, Leikauf G. T-cell receptor V $\beta$ gene segment expression in diisocyanate-induced occupational asthma. J Allergy Clin Immunol. 1997;99(2):245-50, https://doi.org/10.1016/S00916749(97)70104-0.

13. Leng G. 1,5-Naphthylendiisocyanat (NDI) [BAT Value Documentation in German language, 2009]. The MAKCollection for Occupational Health and Safety. Weinheim: Wiley-VCH Verlag GmbH \& Co. KGaA; 2002, https://doi. org/10.1002/3527600418.bb317372d0015. German.

14. Deutsche Forschungsgemeinschaft. Diisocyanates [MAK Value Documentation, 2013]. The MAK-Collection for Occupational Health and Safety. Weinheim: Wiley-VCH Verlag GmbH \& Co. KGaA; 2002, https://doi.org/10.10 02/3527600418.mb0dicygrpe1013.
15. International Agency for Research on Cancer (IARC). Working Group on the Evaluation of Carcinogenic Risks to Humans. 1,5-Naphthalene diisocyanate. IARC Monogr Eval Carcinog Risks Hum. 1999;71 Pt 3:1515-7.

16. Alexandersson R, Gustafsson P, Hedenstierna G, Rosen G. Exposure to naphthalene-diisocyanate in a rubber plant: Symptoms and lung function. Arch Environ Health. 1986; 41(2):85-9, https://doi.org/10.1080/00039896.1986.9937414.

17. Diller WF, Alt E, Klebert W. [Lung function analytical field study of workers exposed to 1,5-naphthylene diisocyanate]. Zentralbl Arbeitsmed Arbeitsschutz Prophyl Ergonomie. 1985;35:82-4. German.

18. Baur X, Chen Z, Marczynski B. Respiratory diseases caused by occupational exposure to 1,5-naphthalene-diisocyanate (NDI): Results of workplace-related challenge tests and antibody analyses. Am J Ind Med. 2001;39(4):369-72, https:// doi.org/10.1002/ajim.1027.

19. Schutze D, Sepai O, Lewalter J, Miksche L, Henschler D, Sabbioni G. Biomonitoring of workers exposed to 4,4'-methylenedianiline or 4,4'-methylenediphenyl diisocyanate. Carcinogenesis. 1995;16(3):573-82, https://doi.org/10.1093/car$\operatorname{cin} / 16.3 .573$.

20. Sepai O, Henschler D, Sabbioni G. Albumin adducts, hemoglobin adducts and urinary metabolites in workers exposed to 4,4'-methylenediphenyl diisocyanate. Carcinogenesis. 1995; 16(10):2583-7, https://doi.org/10.1093/carcin/16.10.2583.

21. Sabbioni G, Wesp H, Lewalter J, Rumler R. Determination of isocyanate biomarkers in construction site workers. Biomarkers. 2007;12(5):468-83, https://doi.org/10.1080/135 47500701395636.

22. Henderson RF, Bechtold WE, Bond JA, Sun JD. The use of biological markers in toxicology. Crit Rev Toxicol. 1989; 20(2):65-82, https://doi.org/10.3109/10408448909017904.

23. Tornqvist M, Fred C, Haglund J, Helleberg H, Paulsson B, Rydberg P. Protein adducts: Quantitative and qualitative aspects of their formation, analysis and applications. J Chromatogr B Analyt Technol Biomed Life Sci. 2002;778(1-2): 279-308, https://doi.org/10.1016/S1570-0232(02)00172-1. 
24. Skipper PL, Tannenbaum SR. Protein adducts in the molecular dosimetry of chemical carcinogens. Carcinogenesis. 1990;11(4):507-18, https://doi.org/10.1093/carcin/11.4.507.

25. Tannenbaum SR, Bryant MS, Skipper PL, Maclure M. Hemoglobin adducts of tobacco-related aromatic amines: Application to molecular epidemiology. Banbury Rep. 1986;23:63-75.

26. Sabbioni G, Skipper PL, Buchi G, Tannenbaum SR. Isolation and characterization of the major serum albumin adduct formed by aflatoxin B1 in vivo in rats. Carcinogenesis. 1987;8(6):819-24, https://doi.org/10.1093/carcin/8.6.819.

27. Van Welie RT, van Dijck RG, Vermeulen NP, van Sittert NJ. Mercapturic acids, protein adducts, and DNA adducts as biomarkers of electrophilic chemicals. Crit Rev Toxicol. 1992;22(5-6):271-306, https://doi.org/10.3109/1040844 9209146310.

28. Wisnewski AV, Srivastava R, Herick C, Xu L, Lemus R, Cain $\mathrm{H}$, et al. Identification of human lung and skin proteins conjugated with hexamethylene diisocyanate in vitro and in vivo. Am J Respir Crit Care Med. 2000;162(6):2330-6, https://doi.org/10.1164/ajrccm.162.6.2002086.

29. Skarping G, Dalene M. Determination of 4,4'-methylenediphenyldianiline (MDA) and identification of isomers in technical-grade MDA in hydrolysed plasma and urine from workers exposed to methylene diphenyldiisocyanate by gas chromatography-mass spectrometry. J Chromatogr B Biomed Appl. 1995;663(2):209-16, https://doi.org/10.1016/ 0378-4347(94)00425-5.

30. Cocker J. Biological monitoring for isocyanates. Ann Occup Hyg. 2011;55(2):127-31, https://doi.org/10.1093/annhyg/ meq083.

31. Maitre A, Berode M, Perdrix A, Romazini S, Savolainen H. Biological monitoring of occupational exposure to toluene diisocyanate. Int Arch Occup Environ Health. 1993;65(2):97-100, https://doi.org/10.1007/BF00405726.

32. Sennbro CJ, Lindh CH, Tinnerberg H, Gustavsson C, Littorin $\mathrm{M}$, Welinder $\mathrm{H}$, et al. Development, validation and characterization of an analytical method for the quantification of hydrolysable urinary metabolites and plasma protein adducts of 2,4- and 2,6-toluene diisocyanate, 1,5-naphthalene diisocyanate and 4,4'-methylenediphenyl diisocyanate. Biomarkers. 2003;8(3-4):204-17, https://doi.org/10.1080/135475 0031000090660.

33. Sennbro CJ, Lindh CH, Mattsson C, Jonsson BA, Tinnerberg H. Biological monitoring of exposure to 1,5-naphthalene diisocyanate and 4,4'-methylenediphenyl diisocyanate. Int Arch Occup Environ Health. 2006;79(8):647-53, https:// doi.org/10.1007/s00420-006-0096-5.

34. Budnik LT, Nowak D, Merget R, Lemiere C, Baur X. Elimination kinetics of diisocyanates after specific inhalative challenges in humans: Mass spectrometry analysis, as a basis for biomonitoring strategies. J Occup Med Toxicol. 2011;6(1):9, https://doi.org/10.1186/1745-6673-6-9.

35. Sepai O, Schutze D, Heinrich U, Hoymann HG, Henschler D, Sabbioni G. Hemoglobin adducts and urine metabolites of 4,4'-methylenedianiline after 4,4'-methylenediphenyl diisocyanate exposure of rats. Chem-Biol Interact. 1995;97(2):185-98, https://doi.org/10.1016/0009-2797(95) 03615-S.

36. Kuck M. Polyisocyanates made from aromatic diisocyanates [Air Monitoring Methods in German language, 1998]. The MAK-Collection for Occupational Health and Safety. Weinheim: Wiley-VCH Verlag GmbH \& Co. KGaA; 2002, https:// doi.org/10.1002/3527600418.am58584d0011. German.

37. Shrivastava A, Gupta V. Methods for the determination of limit of detection and limit of quantitation of the analytical methods. Chron Young Sci. 2011;2(1):21-5, https://doi. org/10.4103/2229-5186.79345.

38. Pauluhn J, Mohr U. Assessment of respiratory hypersensitivity in guinea-pigs sensitized to diphenylmethane-4,4'-diisocyanate (MDI) and challenged with MDI, acetylcholine or MDI-albumin conjugate. Toxicology. 1994;92(1-3):53-74, https://doi.org/10.1016/0300-483X(94)90167-8.

39. Sabbioni G, Lamb JH, Farmer PB, Sepai O. Reactions of 4-methylphenyl isocyanate with amino acids. Biomarkers. 1997;2(4):223-32, https://doi.org/10.1080/135475097231599. 
40. Lind P, Skarping G, Dalene M. Biomarkers of toluene diisocyanate and thermal degradation products of polyurethane, with special reference to the sample preparation. Anal Chim Acta. 1996;333(3):277-83, https://doi.org/10.1016/0003-2670 (96)00291-7.

41. Sabbioni G, Dongari N, Kumar A. Determination of a new biomarker in subjects exposed to 4,4'-methylenediphenyl diisocyanate. Biomarkers. 2010;15(6):508-15, https://doi.org/ 10.3109/1354750X.2010.490880.
42. Lin YS, Kupper LL, Rappaport SM. Air samples versus biomarkers for epidemiology. Occup Environ Med. 2005;62(11):750-60, https://doi.org/10.1136/oem.2004.013102.

43. Littorin M, Truedsson L, Welinder H, Skarping G, Martensson U, Sjoholm AG. Acute respiratory disorder, rhinoconjunctivitis and fever associated with the pyrolysis of polyurethane derived from diphenylmethane diisocyanate. Scand J Work Environ Health. 1994;20(3):216-22, https:// doi.org/10.5271/sjweh.1405.

This work is available in Open Access model and licensed under a Creative Commons Attribution-NonCommercial 3.0 Poland License - http://creativecommons.org/ licenses/by-nc/3.0/pl/deed.en. 